\title{
Measuring Pacemaker Dose: A Clinical Perspective
}

\author{
M. Studenski \\ Thomas Jefferson University and Hospitals \\ Y. Xiao \\ Thomas Jefferson University and Hospitals
}

A. Harrison
Thomas Jefferson University and Hospitals

Follow this and additional works at: https://jdc.jefferson.edu/bodinejournal

Part of the Oncology Commons

Let us know how access to this document benefits you

\section{Recommended Citation}

Studenski, M.; Xiao, Y.; and Harrison, A. (2010) "Measuring Pacemaker Dose: A Clinical Perspective," Bodine Journal: Vol. 3 : Iss. 1 , Article 18.

DOI: https://doi.org/10.29046/TBJ.003.1.017

Available at: https://jdc.jefferson.edu/bodinejournal/vol3/iss1/18

This Article is brought to you for free and open access by the Jefferson Digital Commons. The Jefferson Digital Commons is a service of Thomas Jefferson University's Center for Teaching and Learning (CTL). The Commons is a showcase for Jefferson books and journals, peer-reviewed scholarly publications, unique historical collections from the University archives, and teaching tools. The Jefferson Digital Commons allows researchers and interested readers anywhere in the world to learn about and keep up to date with Jefferson scholarship. This article has been accepted for inclusion in Bodine Journal by an authorized administrator of the Jefferson Digital Commons. For more information, please contact: JeffersonDigitalCommons@jefferson.edu. 


\title{
Measuring Pacemaker Dose: A Clinical Perspective
}

\author{
Studenski, M., Xiao, Y., Harrison, A.
}

Department of Radiation Oncology, Thomas Jefferson University and Hospitals, Philadelphia, PA

\section{Purpose}

The number of patients presenting with pacemakers in our clinic has increased recently. Following AAPM recommendations, a treatment plan is developed that minimizes the dose to the pacemaker. The most efficient way to measure in vivo dose during treatment is to use MOSFETs or diodes which offer a simple but inaccurate (up to $25 \%$ error) method of recording. In this abstract, we analyze the dose measured by these different devices in an attempt to assess pacemaker dose.

\section{Method and Materials}

Five patients with different disease sites and pacemakers were chosen. To simulate the treatment delivery, a Rando phantom was placed on the table in the patient treatment position. An ion chamber was taped to the phantom under $1 \mathrm{~cm}$ bolus. Two MOSFETs and a diode were placed on top of the bolus and the treatment was delivered. One cone beam CT was obtained where the pacemaker was in the field-of-view to quantify the MOSFET and diode reading in this situation.

\section{Results}

The measurement from the ion chamber agreed well with the predicted dose from the planning system. Some errors resulted from misalignment of the phantom and ion chamber. Both the MOSFET and diode measurements agreed with the ion chamber and TPS with greater distances. Dose from CBCT was overestimated for both MOSFETs and diodes.

\section{Conclusion}

The simplest and most efficient in vivo measurement is to use a MOSFET or diode. When the pacemaker is more than $20 \mathrm{~cm}$ from the field edge these dosimeters are appropriate. When the field is less than $20 \mathrm{~cm}$ away, the most accurate although inefficient method is to use an ion chamber since there is little angular or energy dependence unlike diodes or MOSFETs. Another solution would be to use TLDs or OSL dosimeters although these are not simplistic dosimeters either. 